\title{
Properties of Cu-Co Composite Catalysts for Synthesis of Aliphatic Alcohols
}

\author{
Mayya V. Kulikova, ${ }^{\circledR *}, a$ Mariya V. Chudakova, ${ }^{a}$ Mikhail I. Ivantsov, ${ }^{a}$ Alexei E. Kuz'min, ${ }^{a}$ \\ Alla Yu. Krylova a and Anton L. Maksimov ${ }^{a}$
}

${ }^{a}$ A.V.Topchiev Institute of Petrochemical Synthesis, Russian Academy of Sciences, 119991 Moscow, Russia

\begin{abstract}
$\mathrm{Cu}-\mathrm{Co}$-containing cellulose-based carbon composite materials $(\mathrm{Cu}-\mathrm{Co} / \mathrm{Cel})$ were formed by a matrix isolation method. Using X-ray diffraction (XRD), transmission electron microscopy (TEM), infrared-Fourier spectroscopy (IR-Fourier spectroscopy), and non-isothermal research methods, the physicochemical properties of the composites were established. The catalysts are nanosized particles distributed in a carbon matrix, containing fragments of a system of conjugated bonds $(\mathrm{C}=\mathrm{C}-\mathrm{C}=\mathrm{C})$ of various lengths. $\mathrm{Cu}-\mathrm{Co} / \mathrm{Cel}$ catalysts are active in the synthesis of alcohols from $\mathrm{CO}$ and $\mathrm{H}_{2}$, demonstrating high $\mathrm{CO}$ conversion $(68 \%)$ and specific activity $\left(17 \mathrm{~mol} \mathrm{CO} \mathrm{g} \mathrm{Me}^{-1} \mathrm{~s}^{-1}\right)$. Differences in the mechanism of alcohol formation from $\mathrm{CO}$ and $\mathrm{H}_{2}$ on cellulose-based composites and an oxide support (comparison catalyst) were shown by analyzing the distribution of synthesis products.
\end{abstract}

Keywords: dispersed phase catalysis, composite materials, IR-Fourier spectroscopy, in situ magnetometry, nanosized $\mathrm{Cu}-\mathrm{Co}$ catalysts, production of alcohols from synthesis gas

\section{Introduction}

The increased interest in obtaining a mixture of aliphatic alcohols from synthesis gas is due to the possibility of their use as additives to motor fuels, as it leads to an increase in the octane number without increasing the content of aromatic compounds. This reduces the toxicity of exhaust gases and also leads to more complete combustion of fuel due to an increased oxygen concentration. ${ }^{1,2} \mathrm{C}_{3}-\mathrm{C}_{19}$ alcohols are important products of basic organic synthesis. They are used as solvents, stabilizers, plasticizers, flotation agents, and are, also, raw materials for the production of surfactants, polyvinylchloride plasticizers, detergents, synthetic lubricants, pharmaceuticals, paints, and other products. ${ }^{3-5}$

While other processes of synthesis gas conversion to liquid have been commercialized, the commercial success of high alcohol synthesis (HAS) has been limited due to low selectivity and low product yield. The HAS yield in one pass is about $10 \%$ of the synthesis gas conversion to alcohols and methanol, which usually prevails in the composition of products. ${ }^{6,7}$ Methanol can be processed to produce higher molecular weight alcohols or separated and sold. Despite these disadvantages, in 1914, Badische Anilin und Soda Fabrik Societas Europaea (BASF SE) ${ }^{8}$

*e-mail: m_kulikova@ips.ac.ru patented a process for synthesizing a mixture of alcohols, aldehydes, ketones, and other organic compounds from $\mathrm{CO}$ and $\mathrm{H}_{2}$ on an alkaline catalyst based on cobalt oxide at 10-20 MPa and 300-400 ${ }^{\circ} \mathrm{C}$. In 1923, Fischer and Tropsch ${ }^{9}$ developed the "synthol" process for alcohol production using an alkaline $\mathrm{Fe}$ catalyst for synthesis gas conversion to alcohols at $>10 \mathrm{MPa}$ and $400-450{ }^{\circ} \mathrm{C}$.

Between 1935 and 1945, an industrial synthesis of mixed alcohol was carried out using alkalized $\mathrm{ZnO} / \mathrm{Cr}_{2} \mathrm{O}_{3}$ catalysts. Demand for the production of mixed alcohol from synthesis gas declined after 1945 with the increasing availability of oil and desire for pure alcohols for the production of chemicals. ${ }^{10}$ Much of this early work on HAS is detailed in a review by Natta et al. ${ }^{11}$

The process for producing $\mathrm{C}_{2+}$ alcohols was patented by BASF SE in 1913 on a cobalt-containing catalyst at a pressure of $10-20 \mathrm{MPa}$ and a temperature of $300-400{ }^{\circ} \mathrm{C} .{ }^{12}$ This development formed the basis of the synol- and oxyl-processes, where a mixture of oxygen-containing compounds (alcohols, ketones, aldehydes, esters, and acids) was obtained on iron-containing catalysts at 10-30 atm and $180-230{ }^{\circ} \mathrm{C} .{ }^{13}$ However, the processes have lost their relevance due to the complexity of the hardware design and problems with separation of the multicomponent mixture.

Currently, XTL processes (where X-coal, biomass, gas-to-liquid) are actively being developed, which makes it possible to turn any type of organic raw material into 
synthesis gas and, then, into liquid products (hydrocarbons or alcohols). On one hand, this method allows the disposal of waste and the use of renewable sources of raw materials, and on the other hand, it provides valuable petrochemical products with high added value. A more specific goal of research in the synthesis of $\mathrm{C}_{2}-\mathrm{C}_{6}$ alcohols is related to the prospect of their use as high-octane additives to oil fuel. The availability of such mixed fuels derived from biomass can have a significant impact on the development of alternative fuels. The development of new catalysts, that allow the production of mixtures of methanol and higher alcohols, would be especially useful for the production of such fuels.

The catalysts for producing alcohols from synthesis gas are essentially bifunctional catalysts, combining the functions of hydrogenation and polymerization. Depending on the composition, they are usually divided into several groups: (i) modified zinc-chromium catalysts for the synthesis of high-pressure methanol, (ii) modified coppercontaining low-pressure methanol synthesis catalysts, (iii) modified cobalt or iron-containing Fischer-Tropsch (FT) catalysts, and (iv) modified molybdenum liquid phase hydrogenation catalysts (mainly $\mathrm{MoS}_{2}$ ). ${ }^{14-20}$

To date, the most promising catalysts for the production of mixed alcohols are modified catalysts for methanol and Fischer-Tropsch syntheses (FTS). Of particular interest are $\mathrm{Cu}-\mathrm{Co}$ catalysts, combining the properties of both types of catalyst systems. Much attention is paid to the preparation of $\mathrm{Cu}-\mathrm{Co}$ catalysts. In particular, bimetallic nanoparticles (without support), obtained by the reduction of salts in the presence of sodium borohydride, exhibit an alcohol selectivity of about $51 \% .{ }^{21}$ However, for the synthesis of alcohols, supported $\mathrm{Cu}$-Co catalysts are more often used. For example, Cu-Co catalysts deposited on carbon nanotubes by ultrasonic treatment by impregnation at $40 \mathrm{~atm}$ and $290{ }^{\circ} \mathrm{C}$ demonstrate $\mathrm{CO}$ conversion up to $18 \% .{ }^{22}$ In the study of $\mathrm{Cu}$-Co catalysts prepared by different methods, special attention is paid to methods that allow the formation of structured precursors with original physicochemical and catalytic properties. Thus, a $\mathrm{Cu} / \mathrm{Co} / \mathrm{Al}$ catalyst $(1: 2: 1.5)$, previously described, was obtained by coprecipitation of metal salts on a carbon fiber. ${ }^{23}$ Its distinctive feature is that the precursor has the structure of layered double hydroxide. The conversion of $\mathrm{CO}$, at $40 \mathrm{~atm}$ and $240{ }^{\circ} \mathrm{C}$, on the most active catalyst of this type reached $38.5 \%$ with an alcohol selectivity of $47.3 \%$.

Bimetallic $\mathrm{Cu}-\mathrm{Co}$ catalysts were also obtained by preliminary formation of the perovskite structure $\mathrm{CuO} / \mathrm{LaCoO}_{3}$ precursor. ${ }^{24} \mathrm{CO}$ conversion of $74-95 \%$ and an alcohol selectivity of $24-31 \%$ at $30 \mathrm{~atm}$ and $300{ }^{\circ} \mathrm{C}$ was demonstrated. $\mathrm{Cu}-\mathrm{Co}-\mathrm{Cr}$ and $\mathrm{Cu}-\mathrm{Co}-\mathrm{Al}$ catalysts with alkali metal cations were prepared by decomposition of a homogeneous precursor and coprecipitation. $\mathrm{CO}$ conversion of $21-24 \%$ and an alcohol selectivity of $65-70 \%$ was observed at $120 \mathrm{~atm}$ and $250-310{ }^{\circ} \mathrm{C} .{ }^{25}$

In work by Mouaddib et al.,$^{26}$ the effect of the nature of the oxide support on the properties of bimetallic $\mathrm{Cu}-\mathrm{Co}$ catalysts was studied, and it was shown that, at $10 \mathrm{~atm}$ and $250{ }^{\circ} \mathrm{C}$, the alcohol selectivity varied from 12 to $76 \%$, depending on the support. The nature of the carrier also significantly affected the recoverability and dispersion of metal components.

One of the rapidly developing areas of modern material science is the creation of solid disperse systems. Such materials include, in particular, composites based on polymers. According to Gonçalez et al., ${ }^{27}$ composite materials often have better mechanical properties than conventional materials due to improved thermal, magnetic and sorption properties, and electrical conductivity ${ }^{28-32}$ what potentially contribute to their wide practical application. ${ }^{33}$ Lim et al. ${ }^{34}$ describe that adding a relatively small number of nanoparticles to the matrix can significantly change the properties of the latter.

In these composites, a polymer matrix (or a carbon matrix formed from a polymer) is a dispersed medium for metal and/or oxide nanoparticles distributed in it. In such systems, the polymer (or its conversion products) prevents the agglomeration of nanoparticles, and the porous structure formed during heat treatment facilitates the access of reagents to the nanoparticles of the catalytically active phase. ${ }^{35}$ In this case, the matrix and particles distributed in it can also interact.

Due to physicochemical properties of metal-containing composites, it can exhibit high catalytic activity in various processes. ${ }^{36}$ In work by Xiang and Kruse ${ }^{37}$ a method for synthesizing $\mathrm{Cu}-\mathrm{Co}$ catalysts was described, similar to the metal organic framework (MOF) method. The method consists in the joint decomposition of organic metal salts (in particular oxalates) with the formation of a polymer structure. The obtained bimetallic catalysts showed a conversion, not exceeding $15 \%$, and a selectivity of less than $30 \%$ at $60 \mathrm{~atm}$ and $240{ }^{\circ} \mathrm{C}$. The introduction of Mn or $\mathrm{Nb}$ into the catalyst contributed to an increase in catalytic activity $\left(\chi_{\mathrm{CO}}\right.$, in percentage, less than $30 \%$, with selectivity less than $60 \%$ for the $1 \mathrm{Cu}: 1 \mathrm{Co}: 1 \mathrm{Mn}$ catalyst).

Composites containing metals distributed in matrices obtained from polymers by infrared-pyrolysis (IR-pyrolysis) are active in the catalytic hydrogenation of $\mathrm{CO} .{ }^{38}$ As a consequence its catalytic properties, the structure of the resulting composites is affected by the nature of the polymer matrix and the conditions of the material synthesis. ${ }^{39}$

Earlier, we developed and studied Co and Fe cellulosebased composite materials obtained by matrix isolation 
using IR-pyrolysis..$^{40,41}$ During the synthesis, under the influence of IR-radiation, the composite cellulose loses some of the oxygen, which leads to the formation of a system of conjugated double bonds. In this case, the formation of nanosized metal particles with uniform distribution in the resulting carbon matrix is observed. It should be noted that such catalysts do not require a pre-activation step. The temperature of IR-pyrolysis significantly affects the structure and phase composition of the catalyst and, as a result, its properties in the synthesis of hydrocarbons and aliphatic alcohols from $\mathrm{CO}$ and $\mathrm{H}_{2}$. For example, at an IR-pyrolysis temperature of $350{ }^{\circ} \mathrm{C}$, composite catalysts are formed, obtaining oxygenates containing 76-93\% $\mathrm{C}_{2+}$ alcohols. The aim of this work was the synthesis of $\mathrm{Cu}-\mathrm{Co}$-containing composite materials, obtained by the immobilization of salts on cellulose, followed by heat treatment, the study of its physicochemical properties, and catalytic activity in the synthesis of aliphatic alcohols from $\mathrm{CO}$ and $\mathrm{H}_{2}$.

\section{Experimental}

\section{Preparation of catalysts}

Composite catalysts $(20 \% \mathrm{Cu}-\mathrm{Co} / \mathrm{Cel})$ were prepared as follows: $4.25 \mathrm{~g}$ of copper nitrate $\left(\mathrm{Cu}\left(\mathrm{NO}_{3}\right)_{2} \cdot 3 \mathrm{H}_{2} \mathrm{O}\right.$, 99\%, Acros Organics (Geel, Belgium)) and $1.51 \mathrm{~g}$ of cobalt nitrate $\left(\mathrm{Co}\left(\mathrm{NO}_{3}\right)_{2} \cdot 6 \mathrm{H}_{2} \mathrm{O}, 99 \%\right.$, Acros Organics, (Geel, Belgium)) were dissolved in $10 \mathrm{~mL}$ of distilled water. The ratio of $\mathrm{Cu}: \mathrm{Co}$ was 3:1 (wt.\%: 3.2:1 mol). The resulting solution was impregnated with $6 \mathrm{~g}$ of cellulose (Baikal pulp and paper mill, Baikalsk, Russia). Removal of the solvent was performed in a water bath at $56{ }^{\circ} \mathrm{C}$ with atmospheric pressure and temperature control. Solvent removal was estimated by mass loss to a constant value of $\pm 0.02 \mathrm{~g}$. The samples were subjected to heat treatment in a quartz reactor under an inert atmosphere at $350{ }^{\circ} \mathrm{C}$ for 1 and $3 \mathrm{~h} \mathrm{(Cu-Co/Cel-1} \mathrm{and} \mathrm{Cu}-\mathrm{Co} / \mathrm{Cel}-3$, respectively). The resulting $\mathrm{Cu}-\mathrm{Co} / \mathrm{Cel}$ composite catalysts were finely divided black powders. The ratio of metals in the composite after heat treatment was determined by X-ray fluorescence (XRF) analysis using ARL PERFORM'X 2500 (Thermo Fisher Scientific) with a 2500 VA X-ray tube. The ratio of Cu-to-Co in the composite was 3:1. The content of metal components amounted to $8 \% \mathrm{Co}$ and $30 \% \mathrm{Cu}$ for $\mathrm{Cu}-\mathrm{Co} / \mathrm{Cel}-1$ and $9 \% \mathrm{Co}$ and $27 \% \mathrm{Cu}$ for $\mathrm{Cu}-\mathrm{Co} / \mathrm{Cel}-3$.

The catalyst $\left(20 \% \mathrm{Cu}-\mathrm{Co} / \mathrm{Al}_{2} \mathrm{O}_{3}\right)$ was prepared as follows: $5.35 \mathrm{~g}$ of copper nitrate $\left(\mathrm{Cu}\left(\mathrm{NO}_{3}\right)_{2} \cdot 3 \mathrm{H}_{2} \mathrm{O}, 99 \%\right.$, Acros Organics (Geel, Belgium)) and $1.89 \mathrm{~g}$ of cobalt nitrate $\left(\mathrm{Co}\left(\mathrm{NO}_{3}\right)_{2} \cdot 6 \mathrm{H}_{2} \mathrm{O}, 99 \%\right.$, Acros Organics (Geel, Belgium)) were dissolved in $5 \mathrm{~mL}$ of distilled water. The ratio of $\mathrm{Cu}$ :Co was 3:1 (wt.\%). The resulting solution was impregnated with $6 \mathrm{~g}$ of alumina (OOO "Novomichurinsk catalyst plant”, Novomichurinsk, Russia). The sample was dried in a water bath to a constant weight and then, subjected to heat treatment in a quartz reactor in an inert atmosphere at $350{ }^{\circ} \mathrm{C}$ for $1 \mathrm{~h}$.

\section{Catalytic tests}

The synthesis of alcohols from $\mathrm{CO}$ and $\mathrm{H}_{2}$ was carried out in a flow catalytic unit with a fixed-bed reactor. The catalyst was diluted with an equal volume of quartz to reduce the resistance of the powder layer to gas flow and placed on the quartz layer to prevent the material from spilling out of the reaction zone.

The synthesis was carried out under continuous operation using synthesis gas, $1: 2(\mathrm{~mol}) \mathrm{CO}: \mathrm{H}_{2}$ at a pressure of $5 \mathrm{MPa}$ and gas hourly space velocity (GHSV) $300 \mathrm{~h}^{-1}$. The temperature increase over the range of $230-290{ }^{\circ} \mathrm{C}$ was carried out in a stepwise manner (by $20^{\circ} \mathrm{C}$ every $12 \mathrm{~h}$ ). For the experiment, $12 \mathrm{~h}$ are required to enter the mode and accumulate the necessary amount of reaction products for analysis. At the end of each isothermal regime, gas and liquid samples were taken for analysis.

\section{Analysis of reagents and reaction products}

The initial synthesis gas and gaseous products of the synthesis were analyzed by gas chromatography (GC) on a Krystallux-4000 chromatograph with a thermal conductivity detector and helium as the carrier gas. Two chromatographic columns were used. A column filled with CaA molecular sieves $(3 \mathrm{~m} \times 3 \mathrm{~mm}$ ) was used to separate $\mathrm{CO}$ and $\mathrm{N}_{2}$. Isothermal temperature conditions $\left(80^{\circ} \mathrm{C}\right)$ were used. To separate $\mathrm{CO}_{2}$ and $\mathrm{C}_{1}-\mathrm{C}_{4}$ hydrocarbons, a column filled with Haye Sep R ( $3 \mathrm{~m} \times 3 \mathrm{~mm})$ was used. The temperature mode was programmed to rise from 80 to $200{ }^{\circ} \mathrm{C}$ at $8{ }^{\circ} \mathrm{C} \mathrm{min}^{-1}$.

The mixture of liquid hydrocarbons was analyzed by gas-liquid chromatography on a Kristallux-4000M chromatograph with a flame ionization detector. The gas flow rates were $30 \mathrm{~mL} \mathrm{~min}^{-1}$ for nitrogen, $25 \mathrm{~mL} \mathrm{~min}^{-1}$ for hydrogen, and $250 \mathrm{~mL} \mathrm{~min}^{-1}$ for air. Capillary column was OV-351 $(50 \mathrm{~m} \times 0.32 \mathrm{~mm})$. The temperature was programmed to hold at $50{ }^{\circ} \mathrm{C}$ for $2 \mathrm{~min}$, ramp from 50-260 ${ }^{\circ} \mathrm{C}$ at $6{ }^{\circ} \mathrm{C} \mathrm{min}^{-1}$, ramp from $260-270{ }^{\circ} \mathrm{C}$ at $5{ }^{\circ} \mathrm{C} \mathrm{min}{ }^{-1}$, and, then, hold at $270{ }^{\circ} \mathrm{C}$ for $10 \mathrm{~min}$.

Oxygen-containing products in the aqueous phase were analyzed by gas-liquid chromatography on a Kristallux$4000 \mathrm{M}$ chromatograph with a flame ionization detector. Gas flow rates were $20 \mathrm{~mL} \mathrm{~min}{ }^{-1}$ for helium, $25 \mathrm{~mL} \mathrm{~min}^{-1}$ 
for hydrogen, and $250 \mathrm{~mL} \mathrm{~min}^{-1}$ for air. An HP-FFAP capillary column (nitroterephthalic modified polyethylene glycol; $50 \mathrm{~m} \times 0.32 \mathrm{~mm} \times 0.50 \mu \mathrm{m}$ ) was used for analysis. The sample volume was $0.3 \mu \mathrm{L}$. The temperature was programmed to hold at $70{ }^{\circ} \mathrm{C}$ for $8 \mathrm{~min}$, ramp from $70-110{ }^{\circ} \mathrm{C}$ at $10{ }^{\circ} \mathrm{C} \mathrm{min}^{-1}$, ramp from $110-220{ }^{\circ} \mathrm{C}$ at $15^{\circ} \mathrm{C} \mathrm{min}{ }^{-1}$, and hold at $220^{\circ} \mathrm{C}$ for $10 \mathrm{~min}$. For quantitative calculations, the internal standard method was used, and the standard was isobutyl alcohol.

The following indicators were used to evaluate the activity of the catalyst: $\mathrm{CO}$ conversion (percentage of the mass of reacted $\mathrm{CO}$ to the mass of $\mathrm{CO}$ entering the reaction zone), product yield (number of grams of the product obtained by passing $1 \mathrm{~m}^{3}$ of synthesis gas through the catalyst reduced to normal conditions), activity (A; the number of moles of $\mathrm{CO}$ that reacted per $1 \mathrm{~g}$ of the sum of metals in $1 \mathrm{~s}$ ), space-time yields (STY; the number of grams of the product per volume of catalyst per hour), and selectivity by alcohols $\left(\mathrm{S}_{\mathrm{ROH}}\right.$; the percentage of carbon used to form alcohols related to the total amount of carbon reacted).

\section{Physicochemical studies}

\section{X-ray diffraction $(\mathrm{XRD})$}

Experimental XRD patterns were obtained using a Rotaflex RU-200 X-ray source with a rotating copper anode (Rigaku, Japan); the source operating mode was $50 \mathrm{kV}$ and $160 \mathrm{~mA}$. The source was equipped with a Rigaku D/Max-RC horizontal wide-angle goniometer; $\theta-2 \theta$ scanning was performed according to the Bragg-Brentano scheme. The range of measurement of diffraction angles is $5-80$ degrees in $2 \theta$, and the measurement was carried out in continuous scanning mode with a speed of 1 degree $\min ^{-1}$ and a step of 0.04 degrees. A scintillation counter was used as a detector of diffracted $\mathrm{X}$-ray radiation. The wavelength of monochromatic radiation was 1.542 angstroms.

\section{IR-Fourier spectroscopy}

IR spectra were recorded by reflection on a Hyperion-2000 IR microscope coupled to an IFS-66 v/s Bruker IR spectrometer (range $600-4000 \mathrm{~cm}^{-1}$ ). The test sample was preliminarily ground in a mortar. After mixing, $\mathrm{KBr}$ was tableted, and the IR spectroscopic study was carried out.

\section{The specific surface and porosity}

The samples were studied using a Micromeritics ASAP 2020 instrument by the method of nitrogen capillary condensation at $77 \mathrm{~K}$. The specific surface of the samples was calculated by the BET method (Brunauer-EmmettTeller), and the pore size distribution was calculated by the
BJH method (Barret-Joyner-Halenda) using Micromeritics software. The degassing temperature was chosen, taking into account the stability of the samples upon heating, and sample processing was carried out at $350^{\circ} \mathrm{C}$ for $1 \mathrm{~h}$. (The degassing temperature was chosen, taking into account the stability of the samples when heated). The analysis was carried out in the relative pressure range $\left(\mathrm{P} / \mathrm{P}_{\mathrm{o}}\right)$ of 0.01 to 0.99 .

\section{Electron microscopic investigation}

The samples were investigated on a LEO912 AB OMEGA transmission electron microscope (Zeiss, Germany) with an image resolution of $0.2-0.34 \mathrm{~nm}$ at an accelerating voltage of $60-120 \mathrm{kV}$. The test sample, in the form of a suspension in ethanol or distilled water, was applied to a carbon film located on a copper microgrid. The particle size was determined by visual analysis of microphotographs.

\section{Magnetometric studies in situ}

The investigations were carried out in unit based on a vibrating magnetometer. ${ }^{42}$ The weight of the sample was $20 \mathrm{mg}$, and the magnetic field was set by a constant current source, GPR-30H10D, ranging from -0.8 to $0.8 \mathrm{~T}$. The values of magnetic induction were measured by a RSh1-10 instrument. Oscillations of the measuring cell were performed with a constant amplitude of $0.5 \mathrm{~mm}$ in a vertical plane with a frequency of $30 \mathrm{~Hz}$. The signal was recorded at a frequency of $1 \mathrm{~Hz}$. Measurements were carried out at room temperature.

\section{Thermally programmed studies}

The investigations were carried out in the cell of a vibrating magnetometer with continuous registration of magnetization at a fixed magnetic field of $0.3 \mathrm{~T}$. The precursor was degraded in a stream of high purity Ar while heating at a rate of $10^{\circ} \mathrm{C} \mathrm{min}^{-1}$. Oxidation was carried out in a stream of air while heating at $10{ }^{\circ} \mathrm{C} \mathrm{min}^{-1}$. The formation of $\mathrm{CO}_{2}$ was detected by a selective photoacoustic detector developed in the Prokhorov General Physics Institute of the Russian Academy of Sciences (Megakon).

\section{Results}

\section{Physicochemical studies}

\section{$\mathrm{X}$-ray phase analysis}

Figure 1 shows the XRD patterns for the $\mathrm{Cu}-\mathrm{Co} / \mathrm{Al}_{2} \mathrm{O}_{3}$ and $\mathrm{Cu}-\mathrm{Co} / \mathrm{Cel}$ catalysts with different heat treatment times. The composition of the supported $\mathrm{Cu}-\mathrm{Co} / \mathrm{Al}_{2} \mathrm{O}_{3}$ catalyst is represented by the carrier phase $\left(\gamma-\mathrm{Al}_{2} \mathrm{O}_{3}\right)$ and metal 
oxide phases $\left(\mathrm{CuO}\right.$ and $\left.\mathrm{Co}_{3} \mathrm{O}_{4}\right)$. During the preparation of the $\mathrm{Cu}-\mathrm{Co} / \mathrm{Cel}$ catalyst and heat treatment, the crystalline structure of cellulose is destroyed with the formation of an amorphous phase, which leads to the disappearance in the patterns of signals related to crystalline cellulose (Figure 1). The metal-containing phases in the catalyst are represented by copper and cobalt oxides $\left(\mathrm{CuO}, \mathrm{Co}_{3} \mathrm{O}_{4}\right.$, mixed $\mathrm{Cu}_{2} \mathrm{O}$, and $\mathrm{CoO}$ ) and metallic copper.

By the Scherrer formula, the crystallites' sizes of active metals were estimated. For the $\mathrm{Cu}-\mathrm{Co} / \mathrm{Cel}-1$ sample, the crystallites pure copper size was about $15 \mathrm{~nm}$, and $\mathrm{Cu}-\mathrm{Co} / \mathrm{Cel}-3$ was $30 \mathrm{~nm}$. The copper and cobalt oxides crystallite phases were 2-7 nm in size in the both cases.

The positions of the peaks of the $\mathrm{CoO}$ and $\mathrm{Cu}_{2} \mathrm{O}$ phases coincide, due to the identical type and size of the elementary crystal cells, characteristic of these phases. An increase in the duration of the heat treatment during the preparation of the $\mathrm{Cu}-\mathrm{Co} / \mathrm{Cel}$ catalyst from 1 to $3 \mathrm{~h}$ did not violate the composition of the obtained phases but led to a deeper copper reduction.

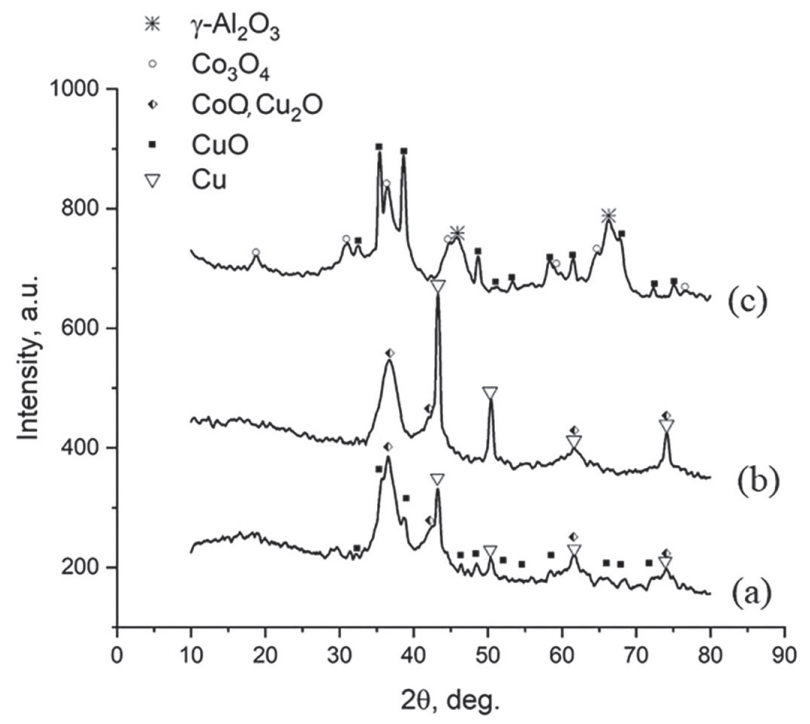

Figure 1. XRD patterns of catalysts $\mathrm{Cu}-\mathrm{Co} / \mathrm{Cel}-1$ (a), $\mathrm{Cu}-\mathrm{Co} / \mathrm{Cel}-3$ (b), and $\mathrm{Cu}-\mathrm{Co} / \mathrm{Al}_{2} \mathrm{O}_{3}$ (c).

\section{Electron microscopy}

Figure 2 demonstrates data on the investigation of the $\mathrm{Cu}-\mathrm{Co} / \mathrm{Cel}$ catalyst by transmission electron microscopy (TEM). Thermo-destruction of the catalyst precursor for $1 \mathrm{~h}$ led to the formation of a homogeneous system of particles in a thermolyzed polymer matrix with an average size of about 6-8 $\mathrm{nm}$ (Figure 2a). Particles larger than $10 \mathrm{~nm}$ made up a small part of the mixture, and particles larger than $18 \mathrm{~nm}$ were not registered at all.

Particles larger than $10 \mathrm{~nm}$ were formed during the $3 \mathrm{~h}$ thermolysis of cobalt and copper salts immobilized on cellulose, and particles larger than $18 \mathrm{~nm}$ also appear (Figure 2b). This indicates nanoparticle enlargement, associated with coalescence of small particles and the formation of larger nanoparticles. This mechanism of nanoparticle growth is supported by the fact that $6-8 \mathrm{~nm}$ nanoparticles remains in the sample, and 2-3 nm particles remain practically unchanged (an alternative process is small particle evaporation and condensation on larger particles, followed by growth of the latter).

\section{Temperature-programmed oxidation}

Temperature-programmed oxidation combined with magnetometric studies allow for conclusions regarding the state of precursors and the nature of their interaction with the carrier. ${ }^{43}$ During the heat treatment of the precursor in an inert medium for 1 and $3 \mathrm{~h}$, systems are formed and characterized by low magnetization values. When comparing the magnetization indices of the systems with the magnetization of a standard sample, $1 \mathrm{mg}$ of metallic cobalt $(829 \mathrm{mV})$, the degree of cobalt reduction was $6-7 \%$. A thermally programmed oxidation of the synthesized materials was carried out in a cell of a vibrating magnetometer in an air stream. Figure 3 shows the characteristic profile of thermally programmed oxidation for a $\mathrm{Cu}-\mathrm{Co} / \mathrm{Cel}-3$ sample.

In the temperature range of $80-180^{\circ} \mathrm{C}$, a slight decrease in magnetization to close of zero was observed, indicating complete oxidation of the cobalt nanoparticles. Formation of $\mathrm{CO}_{2}$, which is associated with the oxidation of the carbon matrix, has not been recorded. Hence, it can be concluded that the oxidation of nanoparticles occurs in the pores of the catalyst and is limited by the diffusion of oxygen. The temperature range of $220-230^{\circ} \mathrm{C}$ is characterized by a sharp increase in intensity and a simultaneous increase in the $\mathrm{CO}_{2}$ emission signal, which indicates decomposition and burnout of the carbon matrix and cobalt reduction by the reaction products. With a further increase in temperature, the formed metallic cobalt is oxidized and passes into the antiferromagnetic state $(\mathrm{CoO})$. The rate of $\mathrm{CO}_{2}$ formation also changes significantly, indicating that the carbon matrix is completely burned out.

The oxidation of nanoparticles of supported catalysts is a complex topochemical process. Diffusion of oxygen in the pores of the support and diffusion of cobalt ions in the oxide layer is limited. ${ }^{44}$ Mugtasimov et al. ${ }^{45}$ showed that the cobalt nanoparticle is coated with a layer of oxide in contact with oxygen, and its thickness depends on the temperature of the reaction and the concentration of the oxidizing agent. Also, the size of the nanoparticle and its shape affects the thickness of the oxide film. ${ }^{46}$ The process of oxide film formation proceeding at the first stage of the 
(a)

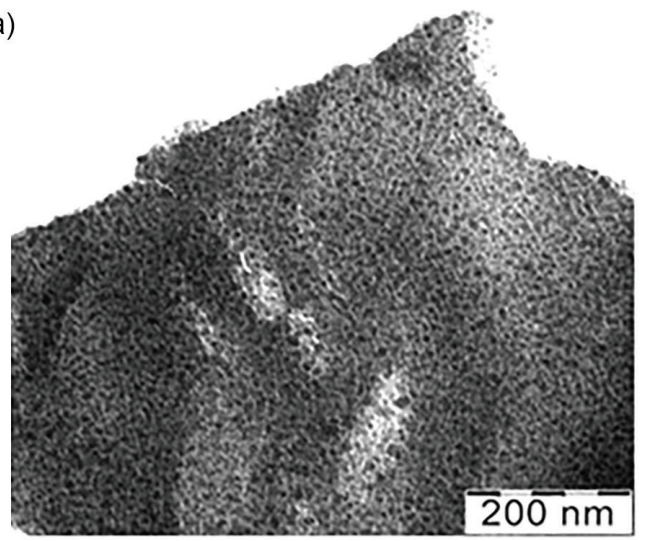

(b)

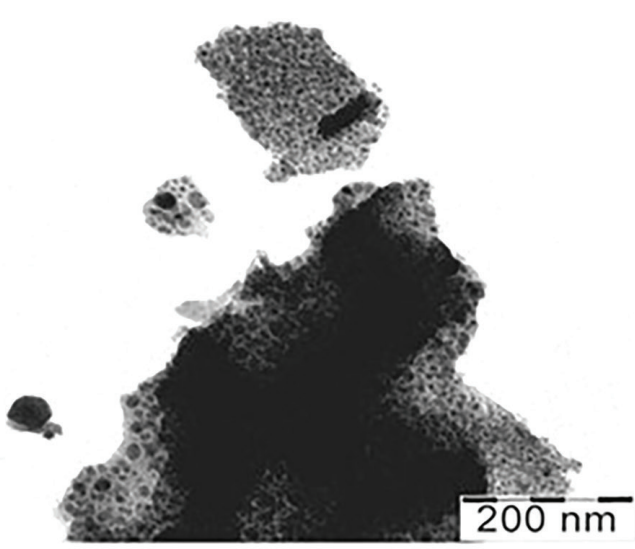

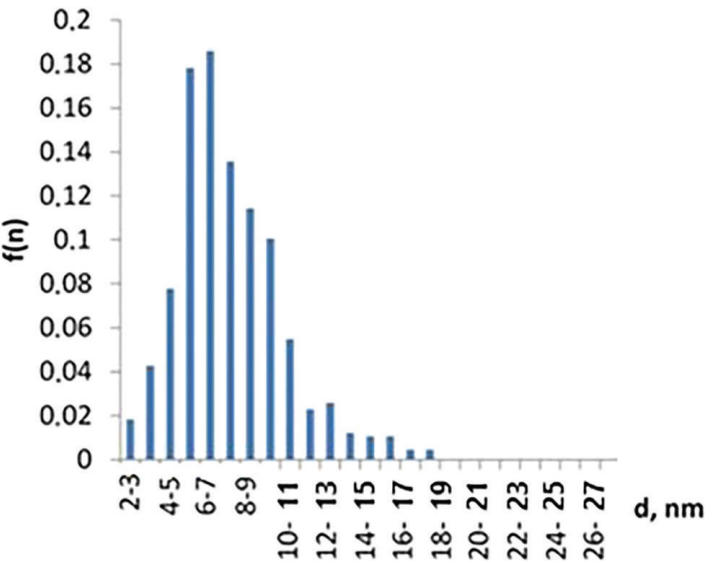

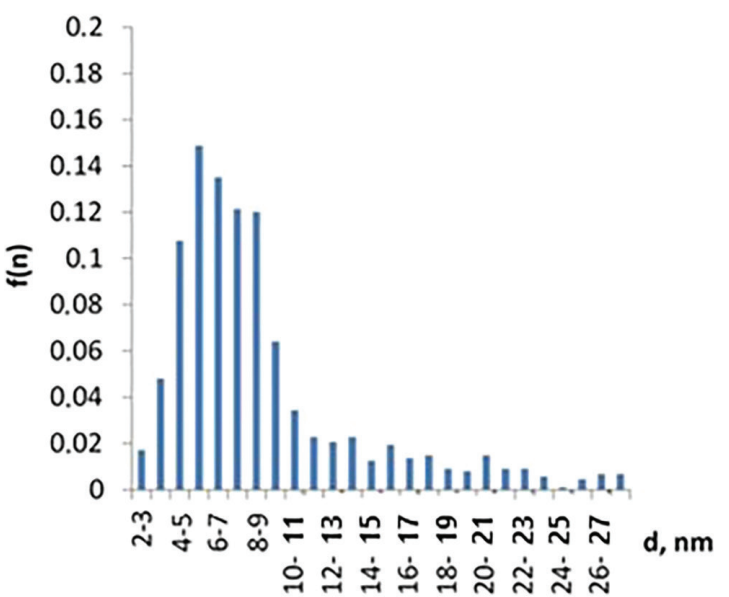

Figure 2. TEM micrographs and particle size distributions for catalyst $\mathrm{Co}-\mathrm{Cu} / \mathrm{Cel}$ after thermo-destruction for $1 \mathrm{~h}$ (a) and $3 \mathrm{~h}$ (b).

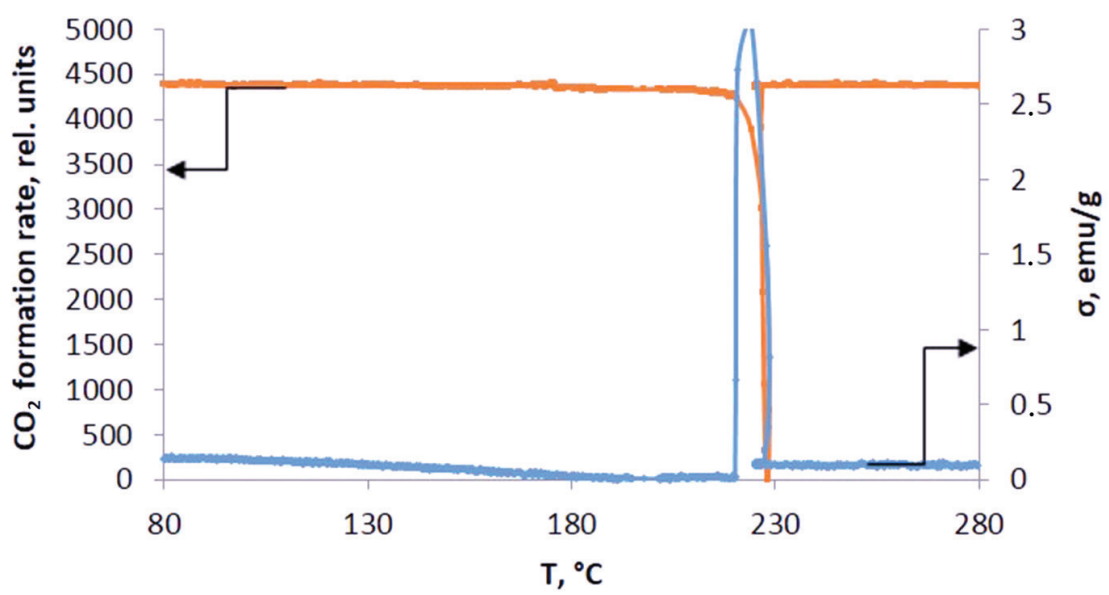

Figure 3. Temperature-programmed oxidation profile of the $\mathrm{Cu}-\mathrm{Co} / \mathrm{Cel}-3$ catalyst.

oxidation process can lead to complete oxidation of the nanoparticle and formation of the corresponding oxide structure. ${ }^{47}$ Thus, the oxidation process occurring in the deposited systems can be divided into two temperature sections: low-temperature (direct, when the oxidizing agent is fed into the cell with the catalyst at room temperature) and high-temperature. Oxidation at room temperature is accompanied by a decrease in the amount of metallic cobalt directly upon contact with an oxidizing agent (associated with the oxidation of superparamagnetic particles). Further oxidation proceeds with increasing temperature, and the process goes into the diffusion region. ${ }^{48-50}$ Thus, the complete oxidation of cobalt nanoparticles occurs from $200-450{ }^{\circ} \mathrm{C}$. 
The specific surface and porosity

The specific surface and porosity were determined by the capillary nitrogen condensation method. It was found that the $\mathrm{Cu}-\mathrm{Co} / \mathrm{Al}_{2} \mathrm{O}_{3}$ catalyst is characterized by a large specific surface area $\left(170 \mathrm{~m}^{2} \mathrm{~g}^{-1}\right)$. The $\mathrm{Cu}-\mathrm{Co} / \mathrm{Cel}-1$ sample had a three-fold lower specific surface $\left(52 \mathrm{~m}^{2} \mathrm{~g}^{-1}\right)$ and an increase in the duration of the heat treatment at the preparation stage of the $\mathrm{Cu}-\mathrm{Co} / \mathrm{Cel}-3$ catalyst, which led to a noticeable increase in the surface (up to $133 \mathrm{~m}^{2} \mathrm{~g}^{-1}$ ).

\section{IR-Fourier spectroscopy}

IR-Fourier spectroscopy was used to study the structural transformations of cellulose during heat treatment of the $\mathrm{Cu}-\mathrm{Co} / \mathrm{Cel}$ catalyst precursor (Figure 4). The precursor spectrum contains bands of nitrate ions at $1311 \mathrm{~cm}^{-1}$ and absorption bands of the original cellulose $\left(1032 \mathrm{~cm}^{-1}\right.$ for $\mathrm{C}-\mathrm{O}$ bonds and $3000-3600 \mathrm{~cm}^{-1}$ for $-\mathrm{OH}$ groups), which were split due to non-covalent interactions with nitrates of metals.

There are no bands of the initial $\mathrm{Cu}-\mathrm{Co} / \mathrm{Cel}$ nitrate ions in the IR spectra of the formed catalysts, which is in good agreement with the thermolysis conditions in an inert medium. The IR spectra of the $\mathrm{Cu}-\mathrm{Co} / \mathrm{Cel}$ catalysts also make it possible to exclude the presence of the original cellulose in the sample, despite a wide average intensity of $3000-3600 \mathrm{~cm}^{-1}$ from -OH groups, since the spectrum does not contain a band characteristic of cellulose at $1032 \mathrm{~cm}^{-1}$ from $\mathrm{C}-\mathrm{O}$ bonds (Figure 4). In the IR spectrum of the $\mathrm{CuCo} / \mathrm{Cel}-1$ catalyst, intense absorption bands are observed at $1570,1375,1242$, and $825 \mathrm{~cm}^{-1}$, which describe the
$\mathrm{C}=\mathrm{C}-\mathrm{C}=\mathrm{C}$ conjugated bond system of various lengths. The high intensity of the $1570 \mathrm{~cm}^{-1}$ band indicates an increased content of short linear mating sections. The sample also contains longer conjugation sites and condensed aromatic rings (several bands in the 1375 and $825 \mathrm{~cm}^{-1}$ region), but the fraction of the latter is small. Double bonds, $\mathrm{C}=\mathrm{N}$, can also enter the conjugation system, in addition to multiple $\mathrm{C}=\mathrm{C}$ bonds. Cellulose nitration can occur during the preparation of the catalyst, but the main bands from nitrocellulose $\left(1660,1283,843\right.$, and $\left.680 \mathrm{~cm}^{-1}\right)$ do not explicitly appear on the spectrum since they coincide with more intense absorption bands from conjugated bonds. An increase in the duration of heat treatment of the precursor leads to a redistribution of the intensity of the absorption bands from the conjugated bonds, due to a change in the length of the conjugated bonds and a decrease in the number of $\mathrm{C}=\mathrm{N}$ bonds.

\section{Catalytic tests}

Catalytic tests of $\mathrm{Cu}-\mathrm{Co} / \mathrm{Cel}$ catalysts in the synthesis of alcohols from $\mathrm{CO}$ and $\mathrm{H}_{2}$ were carried out at a pressure of $0.5 \mathrm{MPa}$ and temperatures of $230-270{ }^{\circ} \mathrm{C}$. The obtained data are presented in Table 1. For comparison, information is presented on the activity of the supported $\mathrm{Cu}-\mathrm{Co} / \mathrm{Al}_{2} \mathrm{O}_{3}$ catalyst under similar conditions.

With an increase of the synthesis temperature, an increase in the conversion of $\mathrm{CO}$ is observed on all catalysts. For the comparison catalyst, $\mathrm{Cu}-\mathrm{Co} / \mathrm{Al}_{2} \mathrm{O}_{3}$, the maximum value of this indicator was $45 \%$ (Table 1). The specific

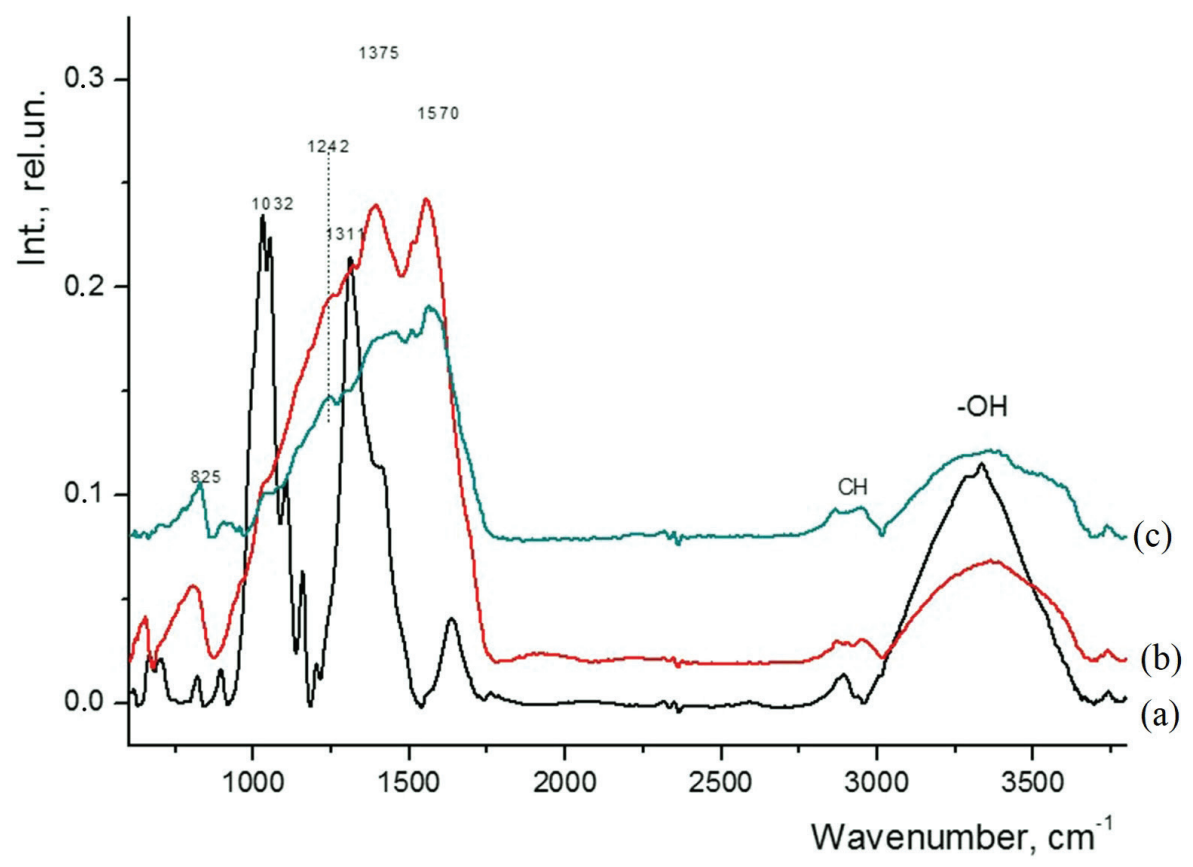

Figure 4. IR (KBr) spectra of precursor and $\mathrm{Cu}-\mathrm{Co} / \mathrm{Cel}$ catalysts: (a) precursor, (b) $\mathrm{Cu}-\mathrm{Co} / \mathrm{Cel}-1$, and (c) $\mathrm{Cu}-\mathrm{Co} / \mathrm{Cel}-3$. 
Table 1. The main characteristics of the $\mathrm{Cu}$-Co catalysts on different supports

\begin{tabular}{|c|c|c|c|c|c|c|}
\hline Catalyst & $\tau / h$ & $\mathrm{~T} /{ }^{\circ} \mathrm{C}$ & $\chi \mathrm{co} / \%$ & $\mathrm{~A} /\left(\mathrm{mol} \mathrm{CO} \mathrm{g} \mathrm{Me}^{-1} \mathrm{~s}^{-1}\right)$ & $\mathrm{S}_{\mathrm{ROH}} / \%$ & $\mathrm{STY} /\left(\mathrm{g} \mathrm{L}^{-1} \mathrm{~h}^{-1}\right)$ \\
\hline \multirow{3}{*}{$\mathrm{Cu}-\mathrm{Co} / \mathrm{Al}_{2} \mathrm{O}_{3}$} & \multirow{3}{*}{-} & 230 & 18.0 & 4.83 & 13.8 & 14.0 \\
\hline & & 250 & 29.4 & 7.87 & 12.5 & 20.0 \\
\hline & & 270 & 44.6 & 11.97 & 14.1 & 34.0 \\
\hline \multirow{6}{*}{$\mathrm{Cu}-\mathrm{Co} / \mathrm{Cel}$} & \multirow{3}{*}{1} & 230 & 12.0 & 2.97 & 0.0 & 0.0 \\
\hline & & 250 & 15.2 & 3.89 & 0.0 & 13.0 \\
\hline & & 270 & 18.8 & 5.22 & 12.2 & 20.0 \\
\hline & \multirow{3}{*}{3} & 230 & 15.8 & 3.34 & 0.0 & 0.0 \\
\hline & & 250 & 38.2 & 9.70 & 10.7 & 22.0 \\
\hline & & 270 & 67.8 & 16.69 & 21.2 & 45.0 \\
\hline
\end{tabular}

$\tau$ : time of heat treatment; T: temperature of catalytic experiment; $\chi$ co: conversion of CO; A: activity of catalyst; $\mathrm{S}_{\mathrm{ROH}}$ : selectivity of alcohol formation; STY space-time yield; $\mathrm{Cu}-\mathrm{Co} / \mathrm{Al}_{2} \mathrm{O}_{3}$ : supported catalyst; $\mathrm{Cu}-\mathrm{Co} / \mathrm{Cel}$ : composite catalyst.

activity of this catalyst (the number of moles of $\mathrm{CO}$ that reacted per $1 \mathrm{~g}$ of the sum of metals in $1 \mathrm{~s}$ ) increased more than two-fold with increasing temperature, reaching $12 \mathrm{~mol} \mathrm{CO} \mathrm{g} \mathrm{Me}^{-1} \mathrm{~s}^{-1}$. CO conversion on the $\mathrm{Cu}-\mathrm{Co} / \mathrm{Cel}-1$ composite catalyst was noticeably lower (the maximum value of this indicator did not exceed 19\%), and its maximum specific activity was only $5 \mathrm{~mol} \mathrm{CO} \mathrm{g} \mathrm{Me}^{-1} \mathrm{~s}^{-1}$. However, a longer heat treatment of the precursor (up to $3 \mathrm{~h}$ ) made it possible to increase the conversion of $\mathrm{CO}$ to $68 \%$. In this case, the maximum specific activity of the $\mathrm{Cu}-\mathrm{Co} / \mathrm{Cel}-3$ composite catalyst reached $17 \mathrm{~mol} \mathrm{CO} \mathrm{g} \mathrm{Me}^{-1} \mathrm{~s}^{-1}$. On the $\mathrm{Cu}-\mathrm{Co} / \mathrm{Al}_{2} \mathrm{O}_{3}$ catalyst, alcohols formed from $\mathrm{CO}$ and $\mathrm{H}_{2}$ over the entire temperature range $\left(230-270{ }^{\circ} \mathrm{C}\right)$ with approximately the same selectivity (Table 1). However, an increase in temperature positively affects the activity of the catalyst and the yield of alcohols. The maximum volumetric yield of alcohols (catalyst productivity) is $34 \mathrm{~g} \mathrm{~L}^{-1} \mathrm{~h}^{-1}$. The formation of alcohols on the composite catalysts is observed above $230^{\circ} \mathrm{C}$ and reaches the highest value at $270{ }^{\circ} \mathrm{C}$ for $\mathrm{Cu}-\mathrm{Co} / \mathrm{Cel}-1$ and $\mathrm{Cu}-\mathrm{Co} / \mathrm{Cel}-3$. The $\mathrm{Cu}-\mathrm{Co} / \mathrm{Cel}-3$ composite catalyst showed maximum selectivity for alcohols (21\%). In this case, the volumetric yield of alcohols reached $45 \mathrm{~g} \mathrm{~L}^{-1} \mathrm{~h}^{-1}$, which is 1.3 times higher than that for the $\mathrm{Cu}-\mathrm{Co} / \mathrm{Al}_{2} \mathrm{O}_{3}$ catalyst.

Data on the composition of alcohols formed from $\mathrm{CO}$ and $\mathrm{H}_{2}$ on the $\mathrm{Cu}-\mathrm{Co} / \mathrm{Al}_{2} \mathrm{O}_{3}$ and $\mathrm{Cu}-\mathrm{Co} / \mathrm{Cell}$ catalysts are presented in Table 2. The alcohol mixtures obtained on the $\mathrm{Cu}-\mathrm{Co} / \mathrm{Al}_{2} \mathrm{O}_{3}$ sample are characterized by a high ethanol content $(60-70 \%)$. In the mixtures obtained on $\mathrm{Cu}-\mathrm{Co} / \mathrm{Cel}$ catalysts, the ethanol content is noticeably lower (30-40\%). However, the concentration of methanol in the mix of alcohols reaches 50-70\%. For catalysts $\mathrm{Cu}-\mathrm{Co} / \mathrm{Al}_{2} \mathrm{O}_{3}$, $\mathrm{Cu}-\mathrm{Co} / \mathrm{Cel}-1$, and $\mathrm{Cu}-\mathrm{Co} / \mathrm{Cel}-3$, the methanol/ethanol ratios for the obtained mixtures are 3.1, 0.45, and 0.37, respectively. We believe this is due to a different mechanism for the formation of alcohols on these catalytic systems.

On the studied systems, along with oxygenates, the formation of hydrocarbons occurs. There was no

Table 2. The composition of the alcohols formed from $\mathrm{CO}$ and $\mathrm{H}_{2}$ on the $\mathrm{Cu}-\mathrm{Co} / \mathrm{Al}_{2} \mathrm{O}_{3}$ and $\mathrm{Cu}-\mathrm{Co} / \mathrm{Cel}$ catalysts

\begin{tabular}{|c|c|c|c|c|c|c|c|c|}
\hline \multirow{2}{*}{ Catalyst } & \multirow{2}{*}{$\begin{array}{c}\text { Treatment time } \\
/ \mathrm{h}\end{array}$} & \multirow{2}{*}{$\begin{array}{c}\text { Synthesis } \\
\text { temperature } /{ }^{\circ} \mathrm{C}\end{array}$} & \multicolumn{6}{|c|}{ The alcohol content / \% } \\
\hline & & & $\mathrm{C}_{1}$ & $\mathrm{C}_{2}$ & $\mathrm{C}_{3}$ & $\mathrm{C}_{4}$ & $\mathrm{C}_{5}$ & $\mathrm{C}_{6}$ \\
\hline \multirow{3}{*}{$\mathrm{Cu}-\mathrm{Co} / \mathrm{Al}_{2} \mathrm{O}_{3}$} & \multirow{3}{*}{-} & 230 & 10.1 & 73.4 & 12.0 & 4.5 & 0.1 & 0.0 \\
\hline & & 250 & 9.8 & 69.5 & 13.0 & 7.1 & 0.5 & 0.0 \\
\hline & & 270 & 14.2 & 64.1 & 14.0 & 6.9 & 0.8 & 0.1 \\
\hline \multirow{6}{*}{$\mathrm{Cu}-\mathrm{Co} / \mathrm{Cel}$} & \multirow{3}{*}{1} & 230 & - & - & - & - & - & - \\
\hline & & 250 & - & - & - & - & - & - \\
\hline & & 270 & 56.4 & 36.3 & 5.6 & 1.5 & 0.3 & 0.0 \\
\hline & \multirow{3}{*}{3} & 230 & - & - & - & - & - & - \\
\hline & & 250 & 49.7 & 40.2 & 6.6 & 3.1 & 0.5 & 0.0 \\
\hline & & 270 & 69.0 & 32.0 & 5.1 & 2.3 & 0.6 & 0.0 \\
\hline
\end{tabular}

$\mathrm{Cu}-\mathrm{Co} / \mathrm{Al}_{2} \mathrm{O}_{3}$ : supported catalyst; $\mathrm{Cu}-\mathrm{Co} / \mathrm{Cel}$ : composite catalyst. 
significant difference in the composition of the resulting liquid hydrocarbons. Both the composite and the deposited catalyst formed a product consisting mainly of paraffins of normal and isostructured fractions of $\mathrm{C}_{5}-\mathrm{C}_{18}$, with a predominance of light hydrocarbons of the gasoline $\left(\mathrm{C}_{5}-\mathrm{C}_{10}\right)$ fraction. The content of other oxygen-containing compounds (acids, esters) in the composition of synthesis products was negligible.

\section{Discussion}

The composite $\mathrm{Cu}-\mathrm{Co} / \mathrm{Cel}$ catalysts that we developed were prepared on the basis of cellulose by matrix isolation. The method involves the immobilization of metal salts on cellulose, followed by heat treatment in an inert atmosphere. The resulting catalysts are metal-containing particles with sizes of 6-18 nm, distributed inside the carbon matrix. The metal-containing phases in the catalyst are represented by copper, cobalt oxides $\left(\mathrm{CuO}, \mathrm{Co}_{3} \mathrm{O}_{4}\right.$, mixed $\mathrm{Cu}_{2} \mathrm{O}$, and $\mathrm{CoO}$ ), metallic copper, and a small amount of metallic cobalt. The appearance of metallic copper can be explained by the interaction of the initial salt with products formed during the decomposition of the polymer during the preparation of the catalyst. ${ }^{39,51}$

According to IR-Fourier spectroscopy, in the process of thermolysis, the original cellulose undergoes significant transformations. Its structure completely disappears, and the organic component of the composites is a complex structure, formed on a polymer chain basis with fragments of conjugated bonds $(\mathrm{C}=\mathrm{C}-\mathrm{C}=\mathrm{C})$ of various lengths, which is characterized by the presence of intense absorption bands at $1570,1375,1242$, and $825 \mathrm{~cm}^{-1}$ in the IR spectrum. Thus, during pyrolysis, the polymer cellulose molecule is destroyed, which is indirectly confirmed by the increasing surface area of the synthesized catalyst.

The activity of the obtained catalysts was compared with the activity of the $\mathrm{Cu}-\mathrm{Co} / \mathrm{Al}_{2} \mathrm{O}_{3}$ catalyst used by

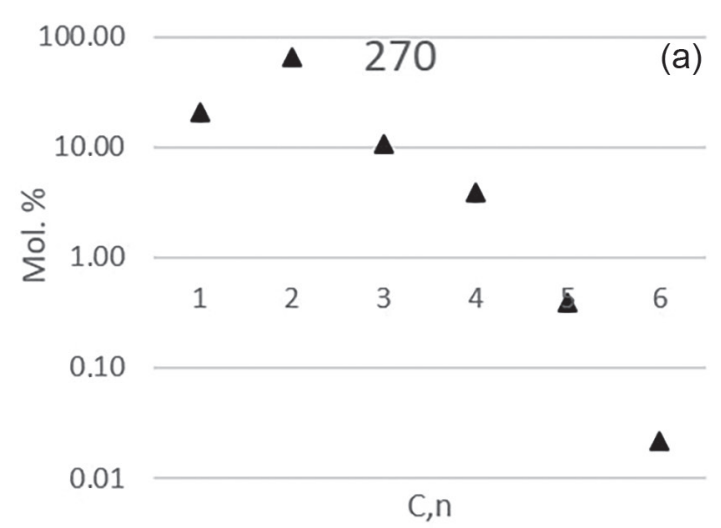

many authors for the synthesis of alcohols from $\mathrm{CO}$ and $\mathrm{H}_{2}{ }^{52}$ It was found that the maximum conversion of $\mathrm{CO}$ on the $\mathrm{Cu}-\mathrm{Co} / \mathrm{Al}_{2} \mathrm{O}_{3}$ catalyst reached $45 \%$ (Table 1 ). The specific activity of this catalyst (the number of moles of $\mathrm{CO}$ reacted per $1 \mathrm{~g}$ of the sum of metals in $1 \mathrm{~s}$ ) was $12 \mathrm{~mol} \mathrm{CO} \mathrm{g} \mathrm{Me}^{-1} \mathrm{~s}^{-1}$. Under similar conditions, the $\mathrm{Cu}-\mathrm{Co} /$ Cel-3 catalyst showed significantly higher $\mathrm{CO}$ conversion $(68 \%)$ and specific activity $\left(17 \mathrm{~mol} \mathrm{CO} \mathrm{g} \mathrm{Me}^{-1} \mathrm{~s}^{-1}\right)$. On the $\mathrm{Cu}-\mathrm{Co} / \mathrm{Al}_{2} \mathrm{O}_{3}$ catalyst, the maximum volumetric yield of alcohols (catalyst productivity) was $34 \mathrm{~mol} \mathrm{CO} \mathrm{g}_{\mathrm{Me}} \mathrm{es}^{-1}$, and on the $\mathrm{Cu}-\mathrm{Co} / \mathrm{Cel}-3$ composite catalyst, a 1.3 -fold higher rate $\left(45 \mathrm{~mol} \mathrm{CO} \mathrm{g} \mathrm{Me}^{-1} \mathrm{~s}^{-1}\right)$ was achieved.

As the time of heat treatment of cellulose increases, the conversion (and overall alcohol selectivity) also increases, despite growth of the particle size. The particle size does not change enough to affect the main indicators of synthesis, whereas specific surface area and porosity increased by two times. We, therefore, believe that we do not observe a decrease in the activity of the catalyst with increasing particle size.

Composition of alcohols formed from $\mathrm{CO}$ and $\mathrm{H}_{2}$ on the $\mathrm{Cu}-\mathrm{Co} / \mathrm{Al}_{2} \mathrm{O}_{3}$ and $\mathrm{Cu}-\mathrm{Co} / \mathrm{Cel}$ catalysts was significantly different. Alcohol mixtures obtained on a $\mathrm{Cu}-\mathrm{Co} / \mathrm{Al}_{2} \mathrm{O}_{3}$ sample were characterized by high ethanol content (60-70\%). In the mixtures obtained on $\mathrm{Cu}-\mathrm{Co} / \mathrm{Cel}$ catalysts, the ethanol content was noticeably lower (30-40\%). However, the methanol concentration in them reached $50-70 \%$. This observation requires more detailed consideration.

Anderson-Schulz-Flory distribution (AFS) (the Anderson-Schulz-Flory equation) of the alcohols obtained on the $\mathrm{Cu}-\mathrm{Co} / \mathrm{Al}_{2} \mathrm{O}_{3}$ and $\mathrm{Cu}-\mathrm{Co} / \mathrm{Cell}$ catalysts was based on $\mathrm{GC}$ analysis. In Figure 5, the molecular mass distribution of the alcohols obtained on the $\mathrm{Cu}-\mathrm{Co} / \mathrm{Al}_{2} \mathrm{O}_{3}$ catalyst is presented.

The obtained dependence does not initially represent a straight line (Figure 5a), as expected. The methanol

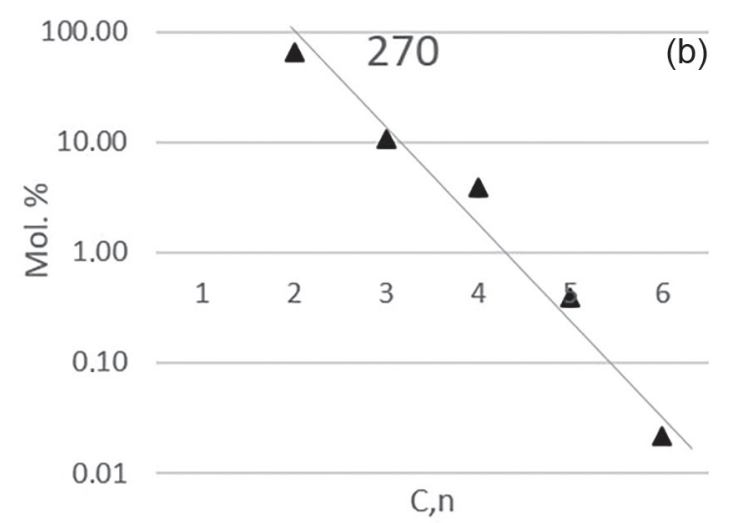

Figure 5. ASF patterns of alcohols obtained on $\mathrm{Cu}-\mathrm{Co} / \mathrm{Al}_{2} \mathrm{O}_{3}$ at $270{ }^{\circ} \mathrm{C}$. (a) Full content of alcohol $\left(\mathrm{C}_{1}-\mathrm{C}_{6}\right)$ obtained, and (b) the alcohol content without methanol $\left(\mathrm{C}_{2}-\mathrm{C}_{6}\right)$. 

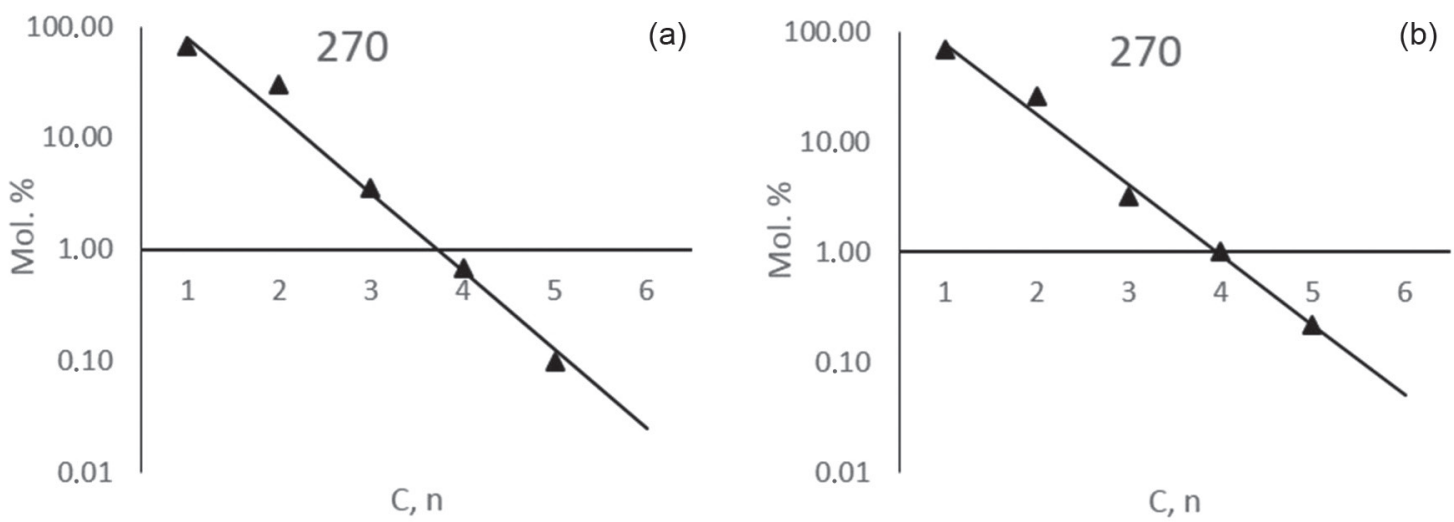

Figure 6. ASF patterns of alcohols obtained on $\mathrm{Cu}-\mathrm{Co} / \mathrm{Cel}-1$ (a) and $\mathrm{Cu}-\mathrm{Co} / \mathrm{Cel}-3$ (b) at $270{ }^{\circ} \mathrm{C}$.

content in the mixture $\left(\mathrm{C}_{1}\right.$ value $)$ clearly drops out; that is, the methanol fraction is lower than expected. Similar results were received from Wang et al. ${ }^{23}$ and Wang et al..$^{52}$ for $\mathrm{Cu}$-Co supported catalysts with a high proportion of $\mathrm{Cu}$. However, if we discard the first point (Figure 5b) the other points (at $\mathrm{C} \geq 2$ ) fit a straight line fairly well. The ASF value calculated from these data is 0.26 . The low concentration of methanol can be explained by its participation in secondary transformations. We believe that, in the $\mathrm{Cu}-\mathrm{Co} /$ $\mathrm{Al}_{2} \mathrm{O}_{3}$ catalyst, the main function is played by copper. The formation of the $\mathrm{Cu}^{0}$ phase, which is responsible for the methanol fragment synthesis on the catalyst surface, was recorded in the $\mathrm{Cu}-\mathrm{Co} / \mathrm{Al}_{2} \mathrm{O}_{3}$ catalyst. Chain growth and the formation of $\mathrm{C}_{2+}$ alcohols occur through the introduction of $\mathrm{CO}$, through the $\mathrm{C}-\mathrm{O}$ bond, similar to the mechanism described previously by Hindermann et al..$^{53}$ Separately, it should be noted that the formation of dimethyl ester did not occur during the catalytic experiment, both in the case of the composite materials and the supported system.

A difference between AFS distribution of alcohols obtained on the $\mathrm{Cu}-\mathrm{Co} / \mathrm{Cel}$ catalysts and $\mathrm{Cu}-\mathrm{Co} / \mathrm{Al}_{2} \mathrm{O}_{3}$ was found. AFS distribution of alcohols obtained on $\mathrm{Cu}-\mathrm{Co} /$ Cel-1 and $\mathrm{Cu}-\mathrm{Co} / \mathrm{Cel}-3$ are presented in Figure 6. In both cases, the dependence is linear, and there are no drops of the $\mathrm{C} 1$ point, characterizing the methanol concentration. The AFS value calculated from these data is 0.20 and 0.23 , respectively, and that corresponds to the AFS Cu-Co catalysts synthesized from oxalates and reduced by hydrogen. ${ }^{54}$

An analysis of the obtained data shows that the formation of alcohols on the $\mathrm{Cu}-\mathrm{Co} / \mathrm{Cel}$ catalysts occurs by a different mechanism from the formation mechanism of alcohols on the $\mathrm{Cu}-\mathrm{Co} / \mathrm{Al}_{2} \mathrm{O}_{3}$ catalyst. In this case, oxymethylene radicals are formed on the surface of the catalyst, followed by polycondensation with the formation of alcohols. This type of mechanism is typical for chain growth on cobalt Fischer-Tropsch synthesis catalysts. ${ }^{55}$
In this case, cobalt plays a determining function, not copper $\mathrm{Cu}^{0}$, with part of the electron density attracted by a system of conjugated bonds. A similar decrease in the charge of $\mathrm{Co}^{0}$, in contrast, has a beneficial effect on the polymerization activity of cobalt catalysts. ${ }^{55}$

\section{Conclusions}

Composite $\mathrm{Cu}-\mathrm{Co} / \mathrm{Cel}$ catalysts, obtained on the basis of cellulose by the matrix isolation method, are made up of particles, up to $20 \mathrm{~nm}$ in size. These particles are distributed inside an organic matrix, which is a complex structure formed on a polymer chain basis with fragments of conjugated bonds $(\mathrm{C}=\mathrm{C}-\mathrm{C}=\mathrm{C})$ of various lengths. $\mathrm{Cu}-\mathrm{Co} / \mathrm{Cel}$ catalysts are active in the synthesis of alcohols from $\mathrm{CO}$ and $\mathrm{H}_{2}$, demonstrating high $\mathrm{CO}$ conversion $(68 \%)$ and specific activity $\left(17 \mathrm{~mol} \mathrm{CO} \mathrm{g}_{\mathrm{Me}}^{-1} \mathrm{~s}^{-1}\right)$. On the $\mathrm{Cu}-\mathrm{Co} / \mathrm{Al}_{2} \mathrm{O}_{3}$ comparison catalyst, the maximum volumetric yield of alcohols (catalyst productivity) reached $34 \mathrm{~g} \mathrm{~L}^{-1} \mathrm{~h}^{-1}$, and the $\mathrm{Cu}-\mathrm{Co} / \mathrm{Cel}-3$ composite catalyst showed a 1.3 -fold higher rate $\left(45 \mathrm{~g} \mathrm{~L}^{-1} \mathrm{~h}^{-1}\right)$. The difference in the mechanisms of the alcohol synthesis from $\mathrm{CO}$ and $\mathrm{H}_{2}$ on catalysts based on cellulose and an oxide support was shown by analyzing the distribution of products. These differences relate to the state of copper. In the $\mathrm{Cu}-\mathrm{Co} / \mathrm{Al}_{2} \mathrm{O}_{3}$ catalyst, metallic copper plays the main role. A methanol fragment is first formed on its surface, and then, chain growth occurs through the introduction of $\mathrm{CO}$ through the $\mathrm{C}-\mathrm{O}$ bond. In the $\mathrm{Cu}-\mathrm{Co} / \mathrm{Cel}$ catalyst, chain growth occurs according to the "cobalt" mechanism of FTS. Oxymethylene radicals are formed on the surface of the catalyst, and $\mathrm{C}_{2+}$ alcohols are formed through their polycondensation. In this case, cobalt plays a determining function, not copper $\mathrm{Cu}^{0}$, because of a decrease in its activity, due to the retraction of part of the $\mathrm{Cu}^{0}$ electron density by a system of conjugated bonds. A similar decrease in the charge of $\mathrm{Co}^{\circ}$, in contrast, has a beneficial effect on the polymerization activity of cobalt catalysts. 


\section{Acknowledgments}

This work was carried out within the State Program of TIPS RAS. This work was performed using the equipment of the Shared Research Center, the analytical center of deep oil processing and petrochemistry of TIPS RAS, and equipment of the Center for Collective Use "New Petrochemical Processes, Polymer Composites and Adhesives".

\section{Author Contributions}

Mayya V. Kulikova was responsible for the conceptualization, investigation, methodology, project administration, resources, supervision, writing of the original draft, reviewing, and editing; Mariya V. Chudakova for data curation, writing the original draft, formal analysis, investigation, visualization, methodology, reviewing, and editing; Mikhail I. Ivantsov for data curation, investigation, writing the original draft, reviewing, and editing; Alexei E. Kuz'min for data curation, methodology, and formal analysis; Alla Y. Krylova for data curation, formal analysis, methodology, reviewing, editing, and supervision; Anton L. Maksimov for data curation, formal analysis, resources, methodology, validation, writing the original draft, reviewing, and editing.

\section{References}

1. Kardasz, P.; Wróbel, R.; J. Ecol. Eng. 2014, 15, 1.

2. Agarwal, A. K.; Prog. Energy Combust. Sci. 2007, 33, 233.

3. Khoshdast, H.; Sam, A.; Open Miner. Process. J. 2011, 4, 25.

4. Kertes, A. S.; King, C. J.; Chem. Rev. 1987, 87, 687.

5. Kosswig K. In Ulmans Encyclopedia of Industrial Chemistry, vol. 35; Wiley-VCH Verlag GmbH \& Co. KGaA: Weinheim, 2012, p. 431.

6. Herman, R. G.; Catal. Today 2000, 55, 233.

7. Wender, I.; Fuel Process. Technol. 1996, 48, 189.

8. Mittasch, A.; Schneider, C.; U.S. pat. 1,201,850, 1916.

9. Fischer, F.; Tropsch, H.; Brennst.-Chem. 1923, 4, 276.

10. Subramani, V. S.; Gangwal, K. A.; Energy Fuels 2008, $22,814$.

11. Natta, G.; Colombo, U.; Pasquon, I. In Catalysis, vol. 5; Emmett, P. H., ed.; Reinhold: New York, 1957, p. 131.

12. Herman, R. G. In New Trends in CO Activation; Guczi, L., ed.; Elsevier: New York, 1991, ch. 7.

13. Forzatti, P.; Tronconi, E.; Pasquon, I.; Catal. Rev. 1991, 33, 109.

14. Luk, H. T.; Mondelli, C.; Ferré, D. C.; Stewart, J. A.; PérezRamírez, J.; Chem. Soc. Rev. 2017, 46, 1358.

15. Surisetty, V. R.; Tavasoli, A.; Dalai, A. K.; Appl. Catal., A 2009 , $365,243$.

16. Surisetty, V. R.; Kumar, A.; Kozinski, D. J.; Appl. Catal., A 2010, 381, 282.
17. Anton, J.; Nebel, J.; Song, H.; Froese, C.; Weide, P.; Ruland, H.; Muhler, M.; Kaluza, S.; Appl. Catal., A 2015, 505, 326.

18. Ishida, T.; Yanagihara, T.; Liu, X.; Ohashi, H.; Hamasaki, A.; Honma, T.; Oji, H.; Yokoyama, T.; Tokunaga, M.; Appl. Catal., A 2013, 458, 145.

19. Walter, K. M.; Serrer, M.-A.; Kleist, W.; Grunwaldt, J.-D.; Appl. Catal., A 2019, 585, 117150.

20. Wang, Z.; Spivey, J. J.; Appl. Catal., A 2015, 507, 75.

21. Subramanian, N. D.; Balaji, G.; Kumar, C. S. S. R.; Spivey, J. J.; Catal. Today 2009, 147, 100.

22. Shi, L.; Chu, W.; Deng, S.; J. Nat. Gas Chem. 2011, 20, 48.

23. Wang, L.; Cao, A.; Liu, G.; Zhang, L.; Liu, Y.; Appl. Surf. Sci. 2016, 360, 77.

24. Fang, Y.; Liu, Y.; Deng, W.; Liu, J.; J. Energy Chem. 2014, 23, 527.

25. Courty, P.; Durand, D.; Freund, E.; Sugier, A.; J. Mol. Catal. 1982, 17, 241.

26. Mouaddib, N.; Perrichon, V.; Martin, G. A.; Appl. Catal., A 1994, 118, 63.

27. Gonçalez, V.; Barcia, F. L.; Soares, B. G.; J. Braz. Chem. Soc. 2006, 17, 1117.

28. Rad, S. D.; Islam, A.; Alnasser, A.; J. Compos. Mater. 2019, 53, 3363 .

29. Zihlif, A. M.; Elimat, Z.; Ragosta, G.; J. Compos. Mater. 2011, 45, 1209.

30. Lima, S. B.; Borges, S. M. S.; Rangel, M. C.; Marchetti, S. G.; J. Braz. Chem. Soc. 2013, 24, 344.

31. Lei, X.-F.; Ma, J.-X.; J. Braz. Chem. Soc. 2010, 21, 209.

32. de Almeida Filho, C.; Zarbin, A. J. G.; J. Braz. Chem. Soc. 2006, $17,1151$.

33. Hussain, F.; Hojjati, M.; Okamoto, M.; Gorga, R. E.; J. Compos. Mater. 2006, 40, 1511.

34. Lim, Y.; Lee, C.; Choi, H.; Bae, J.; J. Compos. Mater. 2017, 51, 2597.

35. Pomogailo, A. D.; Rosenberg, A. S.; Uflyand, I. E.; Metal Nanoparticles in Polymers; Chemistry: Moscow, Russia, 2000, p. 672.

36. Kravchenko, T. A.; Khorolskaya, S. V.; Polyansky, L. N.; Kipriyanova, E. S.; Nanocomposites: Synthesis, Characterization and Applications; Hauppauge: New York, 2013, p. 430.

37. Xiang, Y.; Kruse, N.; J. Energy Chem. 2016, 25, 895.

38. Kulikova, M. V.; Zemtsov, L. M.; Sagitov, S. A.; Efimov, M. N.; Krylova, A. Y.; Karpacheva, G. P.; Khadzhiev, S. N.; Solid Fuel Chem. 2014, 48, 105.

39. Kulikova, M. V.; Ivantsov, M. I.; Efimov, M. N.; Zemtsov, L. M.; Chernavskii, P. A.; Karpacheva, G. P.; Khadzhiev, S. N.; Eur. Chem. Bull. 2015, 4, 181.

40. Khadzhiev, S. N.; Kulikova, M. V.; Ivantsov, M. I.; Zemtsov, L. M.; Karpacheva, G. P.; Muratov, D. G.; Bondarenko, G. N.; Oknina, N. V.; Pet. Chem. 2016, 56, 522. 
41. Chudakova, M. V.; Kulikova, M. V.; Ivantsov, M. I.; Bondarenko, G. N.; Efimov, M. N.; Vasil'ev, A. A.; Zemtsov, L. M.; Karpacheva, G. P.; Khadzhiev, S. N.; Pet. Chem. 2017, 57, 694.

42. Chernavskii, P. A.; Lunin, B. S.; Zakharyan, R. A.; Pankina, G. V.; Perov, N. S.; Instrum. Exp. Tech. 2014, 57, 78.

43. Fadoni, M.; Lucarelli, L. In Adsorption and its Applications in Industry and Environmental Protection, vol. I; Dabrowski, A., ed.; Elsevier: Amsterdam, 1999, p. 177.

44. Chernavskii, P. A.; Pankina, G. V.; Chernavskii, A. P.; Peskov, N. V.; Afanas'ev, P. V.; Perov, N. S.; Tennov, V. A.; Lunin, V. V.; Russ. J. Phys. Chem. A 2006, 80, 1475.

45. Mugtasimov, A. V.; Peskov, N. V.; Pankina, G. V.; Chernavskii, P. A.; Lunin, V. V.; Russ. J. Phys. Chem. A 2011, 85, 217.

46. Ermoline, A.; Dreizin, E. L.; Chem. Phys. Lett. 2011, 505, 47.

47. Chernavskii, P. A.; Pankina, G. V.; Lunin, V. V.; Zaikovskii, V. I.; Peskov, N. V.; Russ. J. Phys. Chem. A 2008, 82, 690.

48. Chernavskii, P. A.; Pankina, G. V.; Lunin, V. V.; Russ. J. Phys. Chem. A 2006, 80, 546.
49. Chernavskii, P. A.; Pankina, G. V.; Lermontov, A. S.; Lunin, V. V.; Kinet. Catal. 2003, 44, 657.

50. Martens, J. H. A.; Van't Blik, H. F. J.; Prins, R.; J. Catal. 1986, 97, 200.

51. Ozkan, S. Z.; Dzidziguri, E. L.; Chernavskii, P. A.; Karpacheva, G. P.; Efimov, M. N.; Bondarenko, G. N.; Nanotechnol. Russ. 2013, 8,452 .

52. Wang, J.; Chernavskii, P. A.; Khodakov, A. Y.; Wang, Y.; J. Catal. 2012, 286, 51.

53. Hindermann, J. P.; Hutchings, G. J.; Kiennemann, A.; Catal. Rev. 1993, 35, 1.

54. Xiang, Y.; Barbosa, R.; Kruse, N.; ACS Catal. 2014, 4, 2792.

55. Lapidus, A. L.; Krylova, A. Y.; Ross. Khim. Zh. 2000, 44, 43.

Submitted: May 1, 2020

Published online: September 4, 2020 